\title{
COMMUNICATION STRATEGIES USED BY TEACHER
}

\author{
Darman Pangaribuan ${ }^{1}$ \\ Universitas Prima Indonesia \\ Stefani Agustina ${ }^{2}$ \\ Universitas Prima Indonesia \\ Anggie Pratiwi ${ }^{3}$ \\ Universitas Prima Indonesia \\ Elfian Manalu ${ }^{4}$ \\ Universitas Prima Indonesia \\ Yenita br Sembiring 5 \\ Universitas Prima Indonesia \\ darman.bambang@gmail.com ${ }^{1}$ \\ Submit, 09-12-2019 Accepted, 30-01-2020 Publish, 07-02-2020
}

\begin{abstract}
This thesis was aimed to find teacher communication strategies during classroom interaction. This research was conducted in SMP SWASTA Brigjend Katamso 1 Medan. The subject of this research was the English Teacher. We used a qualitative approach, more specifically classroom discourse analysis, in analyzing this study since the source of the data were communication strategies which are used by an English teacher in communicating with her students during an English teaching-learning activity. We took the data by recording 90 minutes of English Lessons. We used Faerch and Kasper as a framework for this data analysis, for the reason of its specification and newness. The result showed that the five strategies used were repetition. From those strategies, code-switching was the strategy that was most frequently used by the teacher during the process of teaching and learning. The teacher`s reasons for applying those communication strategies were to overcome the communication barriers that occur between the teacher and the students to help the students understand and memorize the material more accessible. The result of the interview also showed that the students had a good perception of the implementation of communication strategies used by the teacher in the classroom.
\end{abstract}

Keywords: Achievement strategies, communication strategies, reduction strategies, Teacher 


\section{INTRODUCTION}

In learning English, we have to learn all the skills and the component. To make excellent communication in the classroom, language learners sometimes use strategies. Effective classroom interaction has two implications. First, it concerns a pleasant atmosphere in the school-friendly relationships among the participants of the learning process. Second, which is mostly described in the article, encourages students to become effective communicators in a foreign language. It can be achieved through various ways: by implementing different student and teacher roles, exposing students to a different classroom organization, employing a variety of activities, helping students to express themselves, and encouraging their use of communication strategies. If the two implications are joined, we get a pleasant classroom atmosphere in which students are trying to communicate in a foreign language.

To support this study, the researcher took some previous researches. The study is aimed at describing how classroom interaction occurs between teacher educators (TEs) and students in three undergraduate programs of English language teacher education (ELTE) in Bogotá, Colombia, Lucero \& Louse (2017). Thirty-four sessions of classroom instruction of nine TEs were observed and transcribed. Data were analyzed under two methodologies - ethnomethodological conversation analysis (ECA) and self-evaluation of teacher talk (SETT). Cervantes \& Rodriguez (2012), the study is aimed at findings the communication strategies in the beginning EFL classroom. When language learners do not know how to say a word in English, they can communicate effectively by using their hands, imitating sounds, inventing new terms, or describing what they mean. These ways of teaching are communication strategies (CSS). Abunawas (2012) examined CSS used by Jordanian EFL students and the effect of proficiency level in CSS use. The participants of this study consisted of sixty-six students at Zarka University (28 males and 38 females). To collect data, the participants were put into three groups according to their proficiency levels, two instruments were used: picture description test and interviews.

The findings of the study showed that Jordanian University EFL students use various CSS, such as approximation, circumlocution, and code-switching, in spite of their levels of proficiency. Wang (2014) explored Chinese English learners' ability to use CSS. The participants were put in a relatively real English referential communication setting. The analysis of the research data showed that Chinese English learners, when encountering problems in foreign language communication, are characterized by their frequent use of circumlocution, approximation, substitution, exemplification, literal translation, and repetition and word-coinage strategies. The study reported students' infrequent use of culturalknowledge and paralinguistic CSS. The high frequency of literal interpretation, on 
their L1-based approach, suggested that EFL learners' use of L1-based CSS may depend more upon the developmental stage of their target language than the typology distance between L1 and the target language. The findings indicated that learners' use of CSS is influenced by a variety of factors, among which the development stage of their inter-language and their cultural background are identified as two critical factors. Suryati (2015), the study reports a study on teachers' use of interaction strategies in English Language Teaching (ELT) in the lower secondary level of education. The study involved eighteen teachers from Lower Secondary Schools in Malang, East Java. Classroom observation was selected as a method in this study by utilizing Self Evaluation Teacher Talk (SETT) as the instrument.

Former studies on communication strategies have been conducted by researchers (Abunawas, 2012; Suryati, 2015; Rofiatun, 2018). The earlier studies on communication strategies focus on the definition and taxonomy of communication strategies (Faerch \& Kasper, 1983). Somehow, most studies on communication strategies generally have been focused on communication strategies used by L2 learners. In previous studies, approximation was the type of communication strategy that most dominantly used by the teacher (Abunawas, 2012). Rofiatun (2018) stated that code-switching was not recommended. Therefore, the current study is conducted to investigate code-switching as communication strategies used by English teachers during teaching and learning process.

\section{LITERATURE REVIEW}

Speaking is one of the English skills that have to be mastered by students. Speaking is the process of delivering ideas, opinions, or something in someone's mind in oral form. Thornbury (2005) defines speaking as interactive and requires the ability to cooperate in the management of speaking turns. Kayi (2006) added that speaking is a productive skill in oral mode. It, like the other skills, is more complicated than it seems at first and involves more than just pronouncing words. Based on the explanations above, it can be concluded that speaking is an interactive process between teachers and students where the teacher gives the knowledge to the students to produce language as a skill.

\section{Communication Strategies}

Tarone's definition of communication strategies, which has been used productively by many researchers, is one that views.....conscious communication strategies are used by an individual to overcome a crisis which occurs when language structures are inadequate to convey the individual's thought (Tarone: 1980). In the statements above, Tarone points out that communication strategy is a 
systematic attempt by the learners to express or to code the meaning in the target language rules that have not been formatted.

From the perspective of error resources, Brown suggests that communicative strategy is the process of interlingual transfer and the context of learning as a learner tries to get a message through to a hearer or reader (Brown, 1994). To some extent, we may determine some linguistic forms not available to the learner at that point of communication. Then communicative strategies can act as the conscious employment of verbal or nonverbal mechanisms for communicating an idea. Brown's definition of communicative approach can help us to reflect on what strategies have been used by a speaker through the analysis of errors.

From the psychological perspective, Færch and Kasper (1983) define "communicative strategy as potential conscious plans for solving what to an individual presents itself as a problem in reaching a particular communicative goal" (Færch and Kasper 1983). Færch and Kasper explain similar data in terms of an individual's rational response to a problem rather than as a joint response by two people. According to their definition, in general, there are two possible strategies for solving a communication problem: avoidance strategies and achievement strategies.

\section{Model of Communication Strategies}

After reading some definitions of communication strategies, We will begin this section by examining Faerch and Kasper's communication strategies categories. Most of the following policies are connected with problems in the planning phase and some others with issues in the execution phase.

\section{Achievement strategies}

Most of the following policies are connected with problems in the planning phase and some others with issues in the execution phase.

1. Code-switching. When communicating with others in foreign languages, there is always switching from L2 to L1. The extent to which the switching happens depends on the interactants' analysis of the real communicative situation (Færch and Kasper 1983).

2. Inter-lingual transfer. Learners always ignore the IL code when using the codeswitching strategy. However, plans of inter-lingual transfer result in a combination of linguistic features from the IL and L1. The interlingual transfer may not only occur on the phonological level but also at the practical level (Færch \& Kasper 1983). 
3. IL-based strategies. By using their IL system, learners may have several ways of coping with communicative problems, such as generalized, paraphrase, coin new words, or restructure. From the perspective of IL, generalization means that learners solve issues in the planning phase by filling "gaps" in their plans with IL items, which they would not usually use in such context. While, from the perspective of L2, the strategy resembles overgeneralization of an L2 item, as it results in the extension of an object to an inappropriate context.

4. Cooperative strategy. Færch and Kasper (1983) explain "although problems in interaction are necessarily shared problems and can be solved by joint efforts, they originate in either of the interactions, and it is up to him (the speaker) to decide whether to attempt a solution himself or to signal his problems to his interlocutor and attempt to get the problem solved on a cooperative basis."

5. Nonverbal strategy. Nonverbal strategy means the strategy which learners use to replace a lexical item or an action. In our daily communications, individuals often use nonverbal approaches, such as mime, gesture, and sound-imitation. Although nonverbal strategies are less systematic than verbal behavior, it is still essential in interpersonal interaction.

\section{Reduction strategies}

Therefore, reduction strategies play an essential role in learners' process of second language acquisition.

1. Formal reduction strategies. In Færch and Kasper's reduction strategies, there are two main aspects. Firstly, it is the legal reduction strategies. The formal reduction strategies refer to the reduction by which parts of the linguistic system are avoided. Learners tend to adopt formal reduction strategies mainly for the following two reasons. First of all, learners want to avoid making mistakes. Error avoidance, to some extent, maybe psychologically determined. Some second language learners may fell terribly about communicating in a foreign language. They have forbidden doing this unless they can do so without exhibiting linguistic handicaps. Some second language learners believe that linguistic correctness is a prerequisite for the success of communication. Secondly, second language learners want to increase their fluency. Varadi (1980) argues that second language learners may notice that the elimination of certain formal elements does not interfere with the transmission of meaning. It may facilitate communication by increasing fluency. Tarone (1980) also points out that legal strategies are employed to increase efficiency in speech production.

2. Functional reduction strategies. Færch and Kasper (1983) point out that useful reduction may affect the following three main types of elements of the 
communicative goal: actionable communicative goal, modal communicative goal, and propositional communicative goa

\section{RESEARCH METHOD}

In terms of research methodology, the researcher used qualitative research, which aimed at explaining the types of communication strategies and the process of implementing those strategies by an English Teacher by using the communication strategies from Faerch \& Kasper. English teacher is as the subject of this study. The instrument used in this study were observation, audio recording, and interview. The researcher collected the data by recording the entire activity during the class. Also, the researcher interviewed the teacher to support the findings by asking questions that have been on the list and were determined by the researcher. After the data has been collected, the researcher transfers the data into the script.

\section{FINDINGS}

The data analysis is presented on the table, Table 1 below, in the overall outcome of using communication strategies according to the theory of Faerch and Kasper (1984). All percentages on the elaboration of communication strategies as the result of the data analysis may refer to this table. The following pages will be the display of the effect of data analysis.

Table 1 Communication Strategies Used by English Teacher

\begin{tabular}{llll}
\hline $\begin{array}{l}\text { Types of Communication } \\
\text { Strategy }\end{array}$ & Sub- Categories & Total & Percentage \\
\hline Achievement Strategy & Code-Switching & 68 & $64 \%$ \\
& & \\
\cline { 2 - 3 } & $\begin{array}{l}\text { Interlingual } \\
\text { Transfer }\end{array}$ & 5 & $5 \%$ \\
& IL Based Strategy & 0 & 0 \\
\hline & $\begin{array}{l}\text { Cooperative } \\
\text { Strategy }\end{array}$ & 9 & $8 \%$ \\
& $\begin{array}{l}\text { Non-Verbal } \\
\text { Strategy }\end{array}$ & \\
\hline
\end{tabular}




\begin{tabular}{llll}
\hline Reduction Strategy & $\begin{array}{l}\text { Formal Reduction } \\
\text { Strategy }\end{array}$ & 3 & $3 \%$ \\
\cline { 2 - 4 } & $\begin{array}{l}\text { Functional } \\
\text { Reduction }\end{array}$ & 1 & $1 \%$ \\
& Strategy & & \\
\hline
\end{tabular}

On the following pages, we describe each strategy in communicating with her - seventh-grade students of SMP Swasta Brigjend Katamso 1 Medan in the academic year 2019/2020.

\section{Achievement Strategy}

By using the strategies, the second language learner tries to solve the communicative problems in the planning phase due to insufficient linguistic resources. Most of the following procedure is connected with issues that appear in the conversation script. Those strategies are Code Switching, Interlingual Transfer, IL Based Strategy, Cooperative Strategy, and Non-Verbal Strategy.

\section{Code-Switching}

When communicating with others in a foreign language, there is always switching from L2 to L1. The example below contain the strategy found in the conversation :

(1) T: OKE KITA LANJUTKAN PELAJARAN KEMAREN, YESTERDAY WE LEARN ABOUT? ABOUT? ABOUT?

SS: INTRODUCTION

SAMPLE 1 inferred that

\begin{tabular}{lllr}
\hline No & TEACHER, S UTTERANCES & ANALYSIS & CS FOUND \\
\hline 1. & TEACHER: Good morning, class? & In & this \\
& STUDENTS: Good morning miss & $\begin{array}{l}\text { conversation, both } \\
\text { teachers }\end{array}$ & $\begin{array}{r}\text { and } \\
\text { students } \\
\text { used }\end{array}$ \\
& & English. & \\
& & In & this \\
2. & TEACHER: Once again, Good & conversation, both \\
& morning class & teachers & and \\
& STUDENTS: Good morning miss & students & used \\
& & English. & \\
& & In & this \\
3. & TEACHER: How are you today? & conversation, both \\
& STUDENTS: I am fine, miss, thank & teachers & and \\
& you, and you? & students & used \\
& & English. & \\
\hline
\end{tabular}




\begin{tabular}{|c|c|c|c|}
\hline 4. & $\begin{array}{ll}\text { TEACHER: } & \boldsymbol{O} \boldsymbol{k}, \boldsymbol{M m m} . . \text { let's continue } \\
& \text { our study, Kita } \\
& \text { lanjutkan pelajaran } \\
& \text { kemarin, } \text { Ah... } \\
& \text { yesterday we have to } \\
& \text { learn about? About? } \\
& \text { About? (The teacher is } \\
& \text { repeating. .) } \\
\text { Intro.... } & \\
\text { STUDENTS: } \\
\text { answer... })\end{array}$ & $\begin{array}{l}\text { In this } \\
\text { conversation, the } \\
\text { teacher switched } \\
\text { the language from } \\
\text { English into Bahasa }\end{array}$ & $\begin{array}{l}\text { Code- } \\
\text { Switching }\end{array}$ \\
\hline 5. & $\begin{array}{l}\text { TEACHER: Introduction APA? Of of } \\
\text { of of? ( Teacher is repeating), iya... } \\
\text {.about your self. So, it has already } \\
\text { been evident. Udah selesai you, and } \\
\text { next, now I would like to show you a } \\
\text { video, ya, miss akan tampilkan Ada } \\
\text { dua (Teacher is moving hand) you } \\
\text { dua, there are two videos, ada dua } \\
\text { video, ah. . . it is related to our subject } \\
\text { Masih berhubungan dengan topik } \\
\text { Kita, ok, it's about "introduction" oke, } \\
\text { ahh nanti, later, miss again, I will } \\
\text { show you this video, miss akan } \\
\text { tunjukkan Kamu video in. Then, later I } \\
\text { will ask you, yeah miss Akan Tanya } \\
\text { Kamu, what is it in the dialogue? Apa } \\
\text { yang ada di Dalam dialog in? So, you } \\
\text { have to listen to it, and you have to pay } \\
\text { attention to it. Oke? Oke? oke? } \\
\text { (Gesture) } \\
\text { STUDENTS: Okayyy Miss. ... }\end{array}$ & $\begin{array}{l}\text { In this } \\
\text { conversation, the } \\
\text { teacher switched } \\
\text { the language from } \\
\text { English into Bahasa }\end{array}$ & $\begin{array}{l}\text { Code- } \\
\text { Switching }\end{array}$ \\
\hline 6. & $\begin{array}{l}\text { TEACHER : Masih terpesona } \\
\text { nengok Miss nya? } \\
\text { STUDENT: Nggaaakkkkk.... }\end{array}$ & $\begin{array}{l}\text { In this } \\
\text { conversation, the } \\
\text { teacher used } \\
\text { interlingual transfer } \\
\text { "Sengoku" the } \\
\text { formal Bahasa is } \\
\text { "melihat." }\end{array}$ & $\begin{array}{l}\text { Interlingual } \\
\text { transfer }\end{array}$ \\
\hline
\end{tabular}


7. TEACHER: Ok, now I want to ask Niivh (point the student). With. . . STUDENT: Yes. . .
In this conversation Cooperative teacher and student strategy are active in question and answer
8. TEACHER: May I ask you?

STUDENT: What?

TEACHER: Mmm. . . What is the title of that?

STUDENT: About Introduce and

Greetings.

TEACHER: About Introduce and

Greetings. Is that true?

STUDENTS: Yes.

TEACHER: Yes?

STUDENTS: Yes.
In this conversation teacher and student are active in question and answer
Cooperative strategy
TEACHER: Deja. . . ahh. . . about introduction and greetings, tadi kata si Niivh. He said it's about introduction and greetings. And then, Which sentence $\boldsymbol{y a h}$ (gesture) kalimat mana tadi yang kami lihat dan kami dengar that you see and listen ah, about introduction $\boldsymbol{A d a}$ gak yang kami tangkap? Atau, it's not clear, tidak dapat?

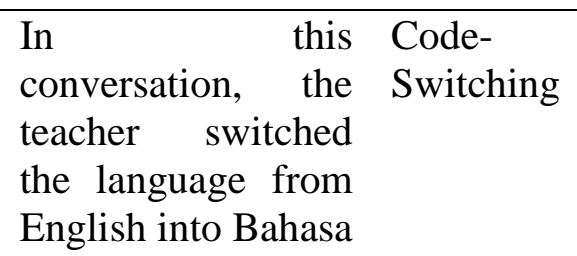

STUDENT: tidak

10. TEACHER: Hello, My name is. . . Hello, my name is. . . (Repeating sentences) is that true? Ada yang nangka tadi? STUDENTS: Ada.
In this
conversation, the Code- teacher switched the language from English into Bahasa 
11. TEACHER: Introduction. . . In this Formal Introductions part, ada lagi? Yes, Joseline (point the student) conversation, the Reduction STUDENT: Selling the computer. ... teacher directly Strategy TEACHER: About introduction nak. mistake

\begin{tabular}{ll}
\hline 12. & TEACHER: MAY ... I... \\
INTRODUCE... MYSELF... He says, \\
May I introduce myself, yah, itu \\
adalah kalimat perke. .nalan. . . Iya \\
kan?? May I introduce myself? What \\
does it mean? Apa artinya it? (gesture) \\
STUDENTS: Bolehkah saya \\
memperkenalkan diri. ...
\end{tabular}

$\begin{array}{lcl}\text { In } & \text { this Nonverbal } \\ \text { conversation, } & \text { the } & \text { Strategy }\end{array}$
teacher made some gestures to help the student understand the lesson STUDENTS. Bolehkah saya improved student,s

13. TEACHER : Bolehkah saya
memperkenalkan diri? Gitu? Masak
sih?
STUDENT: MASAK DI DAPUR. ...

In this Interlingual
conversation, the transfer
teacher used
interlingual transfer
"Masaksih" the
formal Bahasa is
"benarkah?"

\section{STUDENT : Bolehkah saya} In this Nonverbal memperkenalkan diri saya sendiri? TEACHER: Bolehkah saya conversation, the Strategy memperkenalkan diri saya sendiri. . . Yes, That's good, so, before you introduce yourself, don't forget to say "may I introduce myself. .." what else? teacher made some gestures to help the student understand the lesson

Kemarin sudah diajarkan, apalagi? TEACHER AND STUDENTS: Let me introduce myself (point the student) gesture

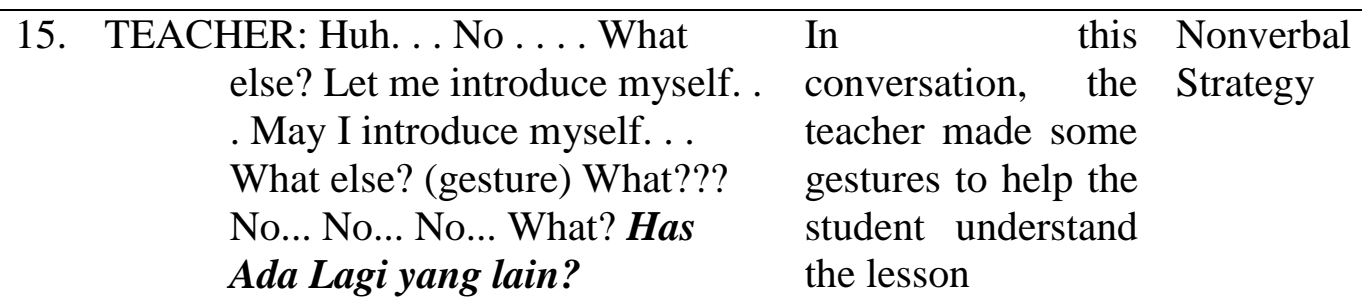
STUDENT: Can I introduce myself?

$\begin{array}{rlrl}\text { 16. TEACHER: He is... he... he ... he } & \text { In } & \text { this } & \text { Formal } \\ \text { sells the computers. So, what } & \text { conversation, the } & \text { Reduction } \\ \text { does he do? Apa pekerjaannya } & \text { teacher directly } & \text { Strategy }\end{array}$




\begin{tabular}{|c|c|c|c|}
\hline & berarti? & improved student,s & \\
\hline & STUDENT : perkantoran & mistake & \\
\hline & TEACHER : Hahh...perkantoran? & & \\
\hline & STUDENT: A seller, Miss. & & \\
\hline 17. & TEACHER: What things that he sells? & In this & Code- \\
\hline & Apa yang dia jual? & conversation, the & Switching \\
\hline & STUDENTS: Computer. & teacher switched & \\
\hline & & the language from & \\
\hline & & English into Bahasa & \\
\hline 18. & TEACHER: Oke Now miss mau & In this & Nonverbal \\
\hline & membagikan kalian kelompok, one & conversation, the & Strategy \\
\hline & grups terdiri dari 4 students kaya yang & teacher made some & \\
\hline & kemarin (Moving hands) & gestures to help the & \\
\hline & STUDENTS: Oooooooooowwww :: & $\begin{array}{l}\text { student understand } \\
\text { the lesson }\end{array}$ & \\
\hline 19. & TEACHER: Oke, This is the last of our & In this & Code- \\
\hline & meeting. Masih Ada 6 Grup Lagi ya & conversation, the & Switching \\
\hline & nak (Moving hands) aaa next week we & teacher switched & \\
\hline & will continue ya hari selasa akan kita & the language from & \\
\hline & lanjutkan. So prepare your self don't & English into Bahasa & \\
\hline & forget to memorize your dialogue, & & \\
\hline & jangan lupa aaa apa namanya & & \\
\hline & (Moving hands) hafal dan diulangi & & \\
\hline & terus, Oke see you (Moving hands) & & \\
\hline & STUDENTS: See you, miss. & & \\
\hline
\end{tabular}

\section{DISCUSSION}

The present study was intended to explore communication strategies used by the teacher in communicating with her students in the classroom. The case study of communication strategies regarding achievement strategy and reduction strategy was elaborated with the academic supports which were relevant to this study. Through combining interview data with classroom observations, it was found that the teacher decided to use achievement strategies, such as codeswitching, nonverbal strategy, cooperative strategy, interlingual transfer, and reduction strategy, such as formal reduction strategy and function reduction strategy as represented on the utterances above. Code-switching was dominantly used to help the students understood what the teacher said. "So, it has already been evident. Udah selesai ya, and next, now I would like to show you a video, ya, miss akan tampilkan ada dua ". This utterance made students understand the lessons easily. Nonverbal strategy, such as, "May I introduce myself? What does 
it mean? (Gestures)"also connected the students to lesson, and communication among teachers and students become more comfortable when the teacher played some gestures. Cooperative strategy, such as, " Ok, now I want to ask Niivh (point the student). With. . . ", encouraged the students to build communication with each other, and also with the teacher.

Overall, the findings of this study are in support of the research of Abunawas (2012) and Lucero (2017), who showed code-switching in communication strategies, and this is also used dominantly in the findings. The results of this study indicate that there are six types of communication strategies used by English teachers during the teaching and learning process. The codeswitching strategy is the one most often used by English teachers during the teaching and learning process (Rofiatun, 2018). Wang (2014) explored Chinese English learners' ability to use CSS. The findings indicated that learners' use of CSS is influenced by a variety of factors, among which the development stage of their inter-language and their cultural background are identified as two critical factors.

Suryati (2015) found that much of the interaction between teachers in Lower Middle School centers on material modes, skills, and system modes. The most common strategies are the initiation response feedback pattern (IRF), display questions, teacher echoes, and extended teacher turnover, while extended student turnover rarely occurs. It was said that to improve Indonesian ELT; there was a need to provide alternatives for ELT class interactions.

\section{CONCLUSION}

Based on the analysis of data in the previous chapter, the writer concludes that first, communication strategies used in classroom interaction were Code Switching, Non Verbal strategy, and Cooperative Strategy. Code-Switching is a combination of two or more languages between sentences. And the dominant Communication Strategy is Non-Verbal Strategy and Cooperative Strategy.

\section{REFERENCES}

Abunawas, S. (2012). Communication Strategies Used by Jordanian EFL Learners. Canadian Social Science. 8(4), 178-193.

Brown, H.D. (1994). Teaching by principles: an Interactive Approach to Language pedagogy. Englewood Cliffs,

Cervantes \& Rodriguez (2012). The Use Of Communication Strategies In The Beginner EFL Classroom, Gist Education And Learning Research Journal. 6(1), 118-128 
Færch, C \& Kasper, G. (1983).Plans and strategies in foreign language communication. In C. Farch and G. Kasper (eds.) Strategies in Interlanguage Communication. Harlow, UK: Longman.

Kayi, H. (2006). Teaching Speaking: Activities to Promote Speaking in a Second Language. The University of Nevada. The Internet TESL Journal, 12(11)

Lucero, E. \& Rose, M. (2017). Classroom Interaction in ELTE Undergraduate Programs: Characteristics and Pedagogical Implications, Colomb. Appl. linguist. Journal., 19(2), 193-208

Rofiatun. (2018). Communication Strategies Used By English Teacher In Teaching And Learning Process, 2nd English Language and Literature International Conference (ELLiC) Proceedings-(ELLiC Proceedings

Suryati, N. (2015). Classroom Interaction Strategies Employed by English Teachers at Lower Secondary Schools. TEFLON Journal, 6(2)

Taron, E. (1980) Communication Strategies, Foreigner talk and repair in interlanguage? Language learning 30(2), 417-413.

Thornbury, S. (2005). How to Teach Speaking. New York: Pearson Education, Inc.

Wang, Dianjian, L., H \& Leslie, M (2014) Chines English Learners' Strategic Competence.Journal of Psycholinguistics Research. Retrieved on 10/4 from http://link.springer.com/article/10.1007/s10936-014-9313-7.

Varadi, T. (1980) Strategies of Target Language Learner Communication: MessageAdjustment. International Review of Applied Linguistics 18(1), $59-71$ 